\title{
IPTEKS STANDAR PELAYANAN PADA PT. TASPEN (PERSERO) CABANG MANADO
}

\author{
Melisa Magda Rangian ${ }^{1}$, Melisa Kumajas ${ }^{2}$, Stanly W. Alexander ${ }^{3}$ \\ ${ }^{1,2}$ Jurusan Akuntansi, Fakultas Ekonomi dan Bisnis, Universitas Sam Ratulangi, Kampus Unsrat, Sulawesi Utara, \\ 95115, Indonesia \\ E-mail : melisaicharangian@gmail.com
}

\begin{abstract}
This study aims to see how well PT TASPEN's service in carrying out its duties in managing pension fund savings for employees, is discussed from several factors that exist within PT TASPEN. PT TASPEN is a non-bank financial institution that works to serve pensioners where pension recipients are only for Civil Servants. The author made observations and interviews to find out the discussion of the factors in this study. The applied science and technology method is related to the implementation of community services with analysis techniques through factors in service. Finally the results of the discussion showed that there was still something to be improved at PT TASPEN to further maximize future work. With suggestions in service procedures there must be an increase in the publication of information in print media or mass media, and in the time of service advice for companies that is to add existing teller services and add information boards.
\end{abstract}

Keywords : TASPEN, service, pension fund, civil servant, community

\section{PENDAHULUAN}

Sektor pemerintahan adalah sektor yang perlu dicermati dengan hati-hati dan sebaikbaiknya karena setiap kebijakan yang diambil sangat berpengaruh bagi seluruh masyarakat, dan untuk membantu kebijakan-kebijakan dalam pemerintahan maka harus ada badan-badan pengelola yang di dalamnya yaitu termasuk Badan Usaha Milik Negara. Penelitian menurut Lembaga Penelitian Universitas Negeri Yogyakarta tahun 2008 dan I Made Asu Dana Yoga Arta tahun 2017, Badan Usaha Milik Negara atau disingkat dengan BUMN yaitu merupakan badan usaha yang dimana seluruh atau sebagian modalnya dimiliki dan bersumber dari pemerintah atau negara. BUMN memiliki bermacam bentuk dan jenis BUMN salah satunya badan usaha Perseroan atau persero yang didalamnya ada PT TASPEN (Persero).

PT TASPEN (Persero) merupakan suatu perusahaan yang dikelola oleh BUMN yang memiliki tugas utama yaitu memberi pelayanan jasa dan melayani transaksi pembayaran kepada peserta pensiun, yang dimana penerima pensiun PT TASPEN (Persero) hanya untuk Pegawai Negeri Sipil atau PNS berdasarkan jurnal A.Setiono., I.Elim., S. Rondonuwu., tahun 2017 dan jurnal Widi Warsita tahun 2016.

Pada PT TASPEN (Persero) dapat juga ditemukan permasalahan dalam pelayanan pengurusan pensiun yaitu masih terdapat kesalahan dan kurangnya ketelitian dalam menginput data dan pelayanan peserta pensiun, sehingga dalam kepengurusannya membutuhkan waktu yang lama, dan terkadang pelayanan tidak sesuai dengan yang sudah ditetapkan standar pelayanan dalam 1jam selesai setelah dokumen diserahkan ke PT TASPEN (Persero) untuk dilakukan pemrosesan.

\section{TINJAUAN PUSTAKA}

Kebijakan Publik. Kebijakan ialah serangkaian tindakan yang mempunyai arah dengan maksud pencapaian tujuan tertentu yang harus dilakukan oleh para pelakunya dalam menyelesaikan suatu persoalan atau masalah. Anderson dalam winarno (2012:21). Kebijakan 
publik ialah pemanfaatan yang strategis terhadap sumber daya yang ada untuk memecahkan masalah-masalah publik atau pemerintah. Chandler \& Plano 1998 dalam (Tangkilisan, 2003:1).

Implementasi Kebijakan. Implementasi ialah suatu penerapan atau pelaksanaan atau tindakan yang telah dibuat dan disepakati secara detail. Menurut Harsono (2002) Implementasi kebijakan merupakan suatu proses yang melaksanakan suatu kebijakan tertentu kemudian mengembangkan kebijakan agar memiliki suatu program yang sempurna. Mazmanian \& Paul Sabatier (1983:61) Implementasi merupakan dasar keputusan kebijaksanaan yang dilaksanakan, biasanya ada dalam bentuk perintah maupun undangundang atau keputusan badan peradilan.

Pelayanan Publik. Sinambela (2011:5) pelayanan publik berarti melayani keperluan orang atau sebagai pemberian layanan kepada masyarakat yang mempunyai kepentingan pada organisasi sesuai dengan aturan yang telah ditetapkan.

Standar Pelayanan. Di dalam pengadaan pelayanan publik harus mempunyai jaminan adanya kepastian bagi penerima pelayanan dimana harus dipublikasikan dan memiliki standar pelayanan. Standar pelayanan ialah ukuran yang telah dibakukan dalam pengadaan pelayanan publik yang wajib ditaati bagi penerima pelayanan atau pemberi pelayanan. Dalam standar pelayanan menurut Keputusan Menteri Pendayagunaan Aparatur Nomor 63 Tahun 2003, standar pelayanan sekurang-kurangnya meliputi : prosedur pelayanan termasuk pengaduan, waktu penyelesaian pengajuan permohonan dan termasuk juga pengaduan, biaya pelaksanaan yang telah ditetapkan, produk pelayanan sesuai dengan ketentuan yang ditetapkan, sarana dan prasarana yang cukup memadai dari penyedia layanan publik. Ada berbagai macam pendapat tentang pelayanan standar yang berkualitas sekaligus memuaskan. Salah satunya menurut pendapat Moenir tahun 2006 petugas harus bisa memenuhi 4 persyaratan pokok agar pelayanan kepada sekelompok orang yg dilayani merasa puas atas pelayanan yang ada adalah sebagai berikut :

1. Waktu penyampaian, menyampaikan suatu hal yang benar-benar tepat.

2. Keramahtamahan, bagian atau komponen di dalam keramahtamahan dapat berupa sebuah layanan lisan yang berhadapan langsung ataupun melalui perantara.

3. Mencerminkan sikap yang sopan/baik, dengan begitu yang bersangkutan merasa dihormati dan dihargai dan merasakan kepuasan tersendiri.

4. Cara menyampaikan, prinsip harus diutamakan dalam cara penyampaian untuk menghindari hal yang menyimpang agar dapat diterima dengan mudah oleh penerima yang bersangkutan.

\section{METODE DAN TEKNIK PENERAPAN IPTEKS}

\subsection{Metode Penerapan Ipteks}

Metode Ipteks yang digunakan adalah menganalisis penerapan standar pelayanan di PT TASPEN (Persero) Manado.

\subsection{Teknik Penerapan Ipteks}

Teknik ipteks yang diterapkan adalah menganalisa standar pelayanan melalui beberapa faktor-faktor yang mempengaruhi yaitu prosedur pelayanan, waktu penyelesaian, biaya pelayanan, produk pelayanan, sarana dan prasarana, serta kompetensi petugas.

\section{PEMBAHASAN}

\subsection{Gambaran Objek Penerapan Ipteks}

PT TASPEN (Persero) Cabang Manado merupakan perusahaan yang dikelola oleh Badan Usaha Milik Negara, yang beroperasi di bidang asuransi sosial Pegawai Negeri Sipil dan Aparatur Sipil Negara, yang berdiri pada tanggal 22 Januari 1990. Mulanya berkedudukan di Jl. Sam Ratulangi Manado namun gedung tersebut hanya disewa, kemudian 
berpindah ke Jl. Ahmad Yani No. 7 Manado sampai saat ini. PT TASPEN (Persero) berlandaskan pada Undang-Undang RI Nomor 40 Tahun 2004 tentang Sistem Jaminan Sosial Nasional (SJSN). Awalnya bentuk perusahaan ini adalah Perusahaan Umum pada tahun 1970 dan berahli menjadi Perusahaan Perseroan ditahun 1981. PT TASPEN (Persero) Cabang Manado memiliki tugas dan tanggungjawab di beberapa daerah seperti Minahasa Utara, Minahasa Tenggara, Minahasa Selatan, Minahasa, Kota Kotamobagu, Kota Tomohon, Kota Manado, Kota Bitung, Kepulauan Talaud, Kepulauan Sitaro, Kepulauan Sangihe, Bolaang Mongondow Utara, Bolaang Mongondow Timur, Bolaang Mongondow Selatan, dan Bolaang Mongondow.

\subsection{Pembahasan}

Faktor-faktor standar pelayanan pada PT TASPEN (Persero) Manado adalah sebagai berikut :

1. Prosedur Pelayanan : Pelaksanaan di kantor TASPEN dapat sesuai dengan tujuan pelayanan publik dan berjalan dengan baik, maka suatu peraturan atau prosedur diperlukan dalam hal ini untuk mengelola data pensiunan dan mengurusnya, sehingga pelayanan yang sangat baik diberikan kepada masyarakat dari PT TASPEN (Persero) Cabang Manado. TASPEN Manado memiliki prosedur pelayanan yang mudah dipahami dan sederhana dalam pelaksanaan bagi peserta pensiun. Di kantor TASPEN Manado cukup mengurus dan melengkapi berkas oleh para peserta pensiun yang diminta dari petugas TASPEN dan setelah semua berkas telah lengkap maka berkas-berkas tersebut dapat diproses di bidang layanan. Dalam persyaratan mengenai pengajuan pensiun harus memenuhi persyaratan SKPP. Tetapi ada sedikit kendala yang terjadi yaitu kurangnya publikasi dalam informasi layanan mengakibatkan masih ada peserta pensiun yang tidak mengetahui jika ada pelayanan Enrollment yang dilaksanakan oleh TASPEN Manado.

2. Waktu Pelayanan : Tentang waktu pelayanan di PT TASPEN (Persero) Manado telah terlaksana sesuai prosedur yang berlaku karena untuk keperluan masing-masing peserta pensiun paling lama hanya memakan 1 jam saja. Untuk pelayanan penyelesaian dalam hal waktu secara keseluruhan untuk pelayanan publik diatur menurut KEP/M.PAN/63/2003. Namun kendala yang ditemukan selama ini, berasal dari ke dua belah pihak, yakni peserta pensiun dan perusahaan ini sendiri. Di mana ketika proses pengajuan klaim berlangsung peserta pensiun seringkali tidak melengkapi berkas sehingga proses penyelesaian berkas otomatis tertunda. Dan kendala yang ditemukan dari perusahaan ini sendiri adanya ketidakseimbangan petugas dan juga peserta pensiun sehingga membuat antrian menjadi cukup panjang dan memakan waktu yang lama.

3. Biaya Pelayanan : Biaya pelayanan dapat diartikan sebagai imbalan atau upah atas pemberian pelayanan yang diberikan. Dalam pelayanan di PT TASPEN (Persero) Manado, tidak melakukan pungutan biaya saat peserta pensiun melakukan pendaftaran di TASPEN atau bisa dikatakan pelayanan di TASPEN Manado adalah GRATIS.

4. Produk Pelayanan : TASPEN Manado sangat berguna bagi kesejahteraan kehidupan Pegawai Negeri Sipil beserta keluarga. Pegawai di TASPEN Manado selalu memberikan pelayanan terbaik, dan melaksanakan tugas dengan baik. Dalam hal ini pensiun menerima pelayanan yang memuaskan dan sesuai dengan apa yang dijanjikan.

5. Sarana dan Prasarana: Di kantor TASPEN Manado sarana dan prasarana yang memadai menjadi salah satu faktor penunjang pelaksanaan pelayanan. Dengan adanya gedung dan ruang tunggu yang bersih dan rapi sehingga terciptanya pelayanan yang nyaman, dan kendaraan mobil dinas yang ada juga dapat mempermudah kegiatan operasional seharihari. Dan juga disediakan minuman bagi para peserta yang menunggu.

6. Kompetensi Petugas : untuk kompetensi petugas pelayanan dapat diukur dari 4 hal yaitu : 
a. Sikap dan perilaku dari para pegawai TASPEN Manado sangat ramah, terutama yang langsung berhadapan dengan para pensiunan dapat dilihat dibagian layanan dan keamanan kantor (satpam).

b. Pengetahuan dari pegawai TASPEN Manado bisa dikatakan memiliki pengetahuan yang cukup luas dan itu dapat dilihat dari cara pegawai menjawab pertanyaanpertanyaan yang diajukan oleh peserta pensiun.

c. Keahlian dari pegawai TASPEN Manado dapat diukur dari hasil kerja disetiap bidang-bidang yang ada, dan para pegawai yang ada sudah cukup menguasai peran dari masing-masing bidang. Dan semua karyawan TASPEN Manado juga menguasai semua bidang-bidang karena dalam perusahaan ini selalu dilaksanakan mutasi bidang pekerjaan. Kendala yang ada misalnya kurang perhatian dalam penyediaan stok kertas dan ketersediaan bahan bakar untuk genset.

d. Keterampilan dari para pegawai cukup baik, namun masih ada beberapa kendala yang membuat para pegawai kurang menguasai teknologi yang ada dan membuat para pegawai saling ketergantungan satu dengan yang lain.

\section{KESIMPULAN DAN SARAN}

\subsection{Kesimpulan}

TASPEN ialah Tabungan dan Asuransi Pegawai Negeri. PT TASPEN (Persero) Cabang Manado sudah melaksanakan tugas dengan baik untuk mengurus mengenai permasalahan dana pensiun, namun ada beberapa hal yang membuat perusahaan ini kurang maksimal dalam melaksanakan pekerjaan itu dapat dibuktikan melalui pembahasan diatas yaitu kurangnya informasi pelayanan sehingga para peserta pensiun tidak mengetahui informasi yang ada seperti pelayanan Enrollment, waktu pelayanan juga mengalami kendala dari pihak peserta dan perusahaan itu sendiri karena terkadang peserta tidak melengkapi berkas yang sesuai dengan syarat dan mengalami penundaan pemrosesan data sedangkan dari perusahaan karena jumlah teller yang ada tidak seimbang dengan jumlah peserta pensiun, dan dalam kompetensi petugas masih kurang perhatian sehingga kendala yang terjadi adalah keterlambatan pelayanan. Jadi untuk memaksimalkan setiap pekerjaan yang ada harus memperbaiki setiap kendala-kendala yang terjadi.

\subsection{Saran}

Berdasarkan masalah yang ada penulis akan memberikan saran dalam prosedur pelayanan harus ada peningkatan publikasi informasi di media cetak atau media massa, dalam waktu pelayanan saran penulis yaitu untuk perusahaan harus menambah pelayanan teller yang ada dan menambah papan informasi agar para peserta sudah mengetahui apa yang harus dilengkapi, dan untuk kompetensi petugas layanan perusahaan harus menyelenggarakan pelatihan-pelatihan khususnya di bidang teknologi dan informasi, dan untuk bagian umum agar dapat mengontrol pengadaan barang dan fasilitas penunjang lainnya.

\section{DAFTAR PUSTAKA}

Fetrya Zuzana, 2013. Pelaksanaan Standar Pelayanan Di PT. TASPEN (PERSERO) Cabang Samarinda. Nomor 4, Volume 1, Halaman 1275-1289.

Hanifah Harsono, 2002, Implementasi Kebijakan dan Politik, Jakarta, Rineka Cipta.

I Made Asu Dana Yoga Arta, 2017. Status Kepemilikan Badan Usaha Milik Negara (BUMN)

Persero Setelah Dikuasai Oleh Pihak Swasta. Nomor 2, Volume 5, Halaman 178-188.

Hessel Nogi S. Tangkilisan. 2003. Kebijakan Publik yang Membumi, Konsep, Strategi dan

Kasus. Yogyakarta: Lukman Offset dan YPAPI.

http://www.taspen.co.id/ 
Keputusan Menteri Pendayagunaan Aparatur Nomor : 63/KEP/M.PAN/7/2003. Tentang Pedoman Umum Penyelenggaraan Pelayanan Publik.

Mazmanian, Daniel H., dan Paul A. Sabatier, 1983, Implementation and Public Policy, New York: HarperCollins.

Moenir. 2006. Manajemen Pelayanan Umum di Indonesia, Jakarta :PT. Bumi Aksara.

Purwanto, 2008. Peran BUMN Dalam Pembinaan dan Pengembangan Usaha Mikro Kecil dan Menengah. Nomor 2, Volume 13, Halaman 19-32.

Sinambela, Litjan Poltak, dkk. 2011. Reformasi Pelayanan Publik: Teori, Kebijakan, dan Implementasi. Jakarta: PT Bumi Aksara.

Undang-Undang RI Nomor 40 Tahun 2004 Tentang Sistem Jaminan Sosial Nasional.

Undang-Undang RI Nomor 11 Tahun 1969 Tentang Pensiun Pegawai dan Pensiun Janda/Duda Pegawai.

Widi Warsita, Endang Larasati Setianingsih, Mochammad Mustam, 2014. Analisis Kualitas Pelayanan Dana Pensiun PT TASPEN (Persero) Kantor Cabang Utama Semarang.

Winarno. 2012. Kebijakan Publik:teori, proses dan studi kasus, Yogyakarta. 